\title{
Greening the economic activity of the mountainous territorial communities of Transcarpathia
}

\author{
Mykhailo Pitiulych ${ }^{1, *}$, Vasyl Miklovda ${ }^{2}$, Volodymyr Hoblyk ${ }^{1}$, Heorhina Kampo ${ }^{2}$, and Vasyl \\ Pigosh $^{1}$ \\ ${ }^{1}$ Mukachevo State University, 26 Uzhhorodska Str., 89600, Mukachevo, Ukraine \\ ${ }^{2}$ Uzhhorod National University, 3 Narodna Sq., 88000, Uzhhorod, Ukraine
}

\begin{abstract}
A conceptual model of the ecological and economic development of the mountainous territorial communities of the Transcarpathian region in the context of the implementation of the administrative-territorial reform and decentralization has been proposed, it makes it possible to effectively use their natural resource, production and human potential, to increase the competitiveness of local economic systems due to the greening of economic activities. The main reasons that determine the deep differentiation in the level of social and economic development of mountain communities in comparison with the communities of the foothills and lowlands of the natural and economic zones of the region have been analyzed. Taking into account the creative factors - the presence of unique natural resources, mineral waters, landscape and climatic zones, forests, significant reserves of groundwater and surface water, historical traditions and features of their ethnic group a model of ecological and economic development of mountain territorial communities has been proposed. The essence, stages of formation have been revealed and the range of tasks to be solved at each of these stages has been determined. Perspective directions of development of mountain communities, which brings them closer to the smart community, have been substantiated.
\end{abstract}

\section{Introduction}

An analysis of the main factors that generate deep differences in social and economic development in spatial terms shows that if at the initial stage of the economic reform they were mainly due to different starting conditions prevailing in the towns and villages of the Transcarpathian region at the beginning of the reforms, then in the current conditions the dynamics of economic processes is determined by purely market factors - the level of development of entrepreneurial activity, the competitiveness of goods and services, the conditions for the formation of costs, prices, supply and demand. As a result, the dynamics of the formation of market relations in the spatial section has increased significantly.

\footnotetext{
${ }^{*}$ Corresponding author: pitjuluch0311@gmail.com
} 
The situation is especially difficult in mountainous territorial communities, which significantly lag behind the regional average in terms of the dynamics of business development, the level of wages, consumption, employment and so on. The current crisis situation and the threat of its further deepening presupposes an objective need to find one's own model of management based on efficient use of own production and human capital, as well as taking into account factors of institutional and evolutionary direction, i.e. taking into account the local model of history, traditions, culture of labor, customs of the population of the territory. Taking into account the creative factors for the mountain communities of Transcarpathia, the model of ecological and economic development is promising, under the influence of which their economic priorities, sectoral structure of the economy, specialization of production, entrepreneurship development, placement of new productions by environmental criteria are formed. This criterion determines the scope of activities of all economic entities in the community and the effectiveness of their own production and human potential, the competitiveness of goods and services.

The purpose of the article is to substantiate the conceptual foundations of the formation of ecological and economic model of mountain territorial communities development of the Transcarpathian region and to clarify the main characteristics of their development that bring them closer to smart-communities.

\section{Analysis of recent research}

The current model of state regulation of the mountainous territories development is mainly aimed at improving interbudgetary relations by providing grants, subventions, additional payments, which, on the one hand, are a means of financing current expenditures, and on the other hand, an attempt to neutralize significant disparities in the income of the population. However, they do not change the proportions of economic development. In fact, the mountainous association of society is assigned the role of a raw material appendage, it is doomed to degradation. From this it becomes obvious that the existing approaches to regulating the development of mountainous territories leave no chances for their revival. The situation is further complicated by the fact that the export of raw materials has been a growth driver for a long time and has practically exhausted itself. Awareness of this quite obvious fact raises an applied problem, the essence of which is the search for a creative model for the development of a mountain settlement. Its framework is based on the broad involvement of the natural resource potential of mountainous areas in the economic turnover. We are talking about the use of the energy of mountain rivers, forests, byproducts of forestry, hunting, mineral water. Their use and especially on-site processing will give an impetus to the diversification of the rural economy and technological renewal.

The retrospective shows that the problem of mountain development is constantly in the center of attention of scientists in various fields of knowledge, being implemented in various strategic documents, concepts and programs. Recently, a number of international scientific and practical conferences have been held in Lviv, Uzhhorod and Ivano-Frankivsk, dedicated to the social and economic development of the mountainous territories of the Ukrainian Carpathians. A number of important problems of development of mountain territories in the conditions of decentralization and administrative-territorial reform were reflected in the works of Ukrainian and foreign scientists V.Kravtsiv [1], M. Pityulych [2], V. Miklovda [3], O. Pavlov [4], P. Zhuk [5], P. Samoliotov [6], U. Schirpke [7], K. Klima [8]. The deepening crisis in the mountain communities of the region necessitates the objective need to find their own model of economic development, which involves the efficient use of their natural and human capital, finding effective mechanisms to attract investment to diversify and modernize their economy and reorient to innovation path of development. 


\section{Results}

The eco-settlement structure of the Transcarpathian region is characterized by a clearly defined spatial vertical zonation, which includes lowland, foothill and mountain natural and economic zones. These administrative-territorial formations differ in natural and climatic conditions, resource and production potential, which imposes certain specifics on economic activity, dynamics and intensity of structural processes, the level of economic activity, business conditions, the situation in local labor markets, living standards.

The existing objective differences create unequal economic conditions, which resulted in the deepening of territorial disparities in the social and economic development of the region. The situation is especially difficult in the territorial communities of the mountain natural and economic zone, where almost every fourth inhabitant of Transcarpathia lives. Of the six newly created districts, 4 have mountain settlements.

Systematic research in the region indicates that the potential for crisis in mountain settlements has been accumulating for decades. This is confirmed by local-factor analysis of the causes that generate a crisis situation in mountain settlements, the main of which are:

- mono-sectoral structure of the economy based on the hypertrophied development of the sector exploiting natural resources. As a result, the economies of many mountain villages have a raw material base and cannot be considered as a factor in overcoming largescale poverty, whereas the vast majority of the rural population does not participate in the distribution of rental income from the use of natural resources, which inevitably leads to a conflict of interest between the community and business structures;

- the narrowness of local rural labor markets and a much higher unemployment rate compared to the regional average, which generates conditions for large-scale labor migration, the core of which is formed by rural youth. Sociological monitoring conducted in the region in 2019-2020 among student youth showed that 39.2 percent of students of vocational schools and almost every fifth university student, if possible, agree to go to a permanent place of residence abroad, and 34, 6 percent of students and 26.1 percent of vocational school students under certain conditions agree to go to work abroad [2]. The current situation creates conditions for the destruction of labor potential and reducing the number of people of working age;

- deformation of the demographic development of the rural population. As of January 1, 2020, in all six districts classified as mountainous natural economic zone, for the first time a reduction in natural population growth was recorded, the share of which in the total reduction of natural population growth in the region is $25.6 \%$. From this we can conclude that mountain villages, today lose their role as the main source of population reproduction (tough they were traditionally over a long period of time) [9]. The analysis of the sex and age structure of the population by individual age groups in 1989-2018 showed a decrease in the share of people younger than working age from 26.5 percent in 1989 to 21.0 percent in 2018. The share of people older than working age for the analyzed period increased from 6.6 to 10.7 percent. Changing the basic proportions between the population and the share of juvenile and gerontological groups will increase the pressure on the working population and increase the costs associated with old-age pensions.

- much lower level of business activity of the mountain population in comparison with its level in the lowland economic zone. Monitoring of business activity of the population of Transcarpathian region showed that the number of legal entities and individualsentrepreneurs in mountain settlements is much smaller than in the lowlands. For example, the number of legal entities in mountain communities per thousand people of the economically active population in the lowlands is 113 people, while in the mountain - only 29. Similarly, the number of individual entrepreneurs is 23 and 9 , respectively. One of the important reasons for the existing differentiation of the level of economic activity is the 
large difference in capital expenditures from the budget for the development of territorial communities, which in mountain communities are 5 times less than in communities of the low-lying natural-economic zone of the region [3]. This situation causes some concern, since the increase in the social activity of the population of mountain communities through inclusion in the sphere of entrepreneurial and commercial activities should be considered as a strategic resource for the improvement of the rural economy.

- infrastructural backwardness and low provision of services to the mountain population. It is not only about social, but also production infrastructure. This situation generates serious negative consequences, which are manifested in the unattractiveness of many rural settlements for housing, investment, slows down the processes of diversification and modernization of the economy, and thus makes it uncompetitive.

Cluster analysis of the social infrastructure provision level, and consequently the level of satisfaction of the population in various services, carried out using the software package SPSS (Version 20) showed that mountain settlements of the region formed the largest group with poorly developed social infrastructure (41.6 percent). At least this means that the formation and development of infrastructure facilities for education, culture, health, road construction should be carried out taking into account the existing asymmetry in the levels of their development in the spatial context based on the real financial capabilities of mountain communities and the necessary state support in the development of social infrastructure.

There are a number of other important issues that hinder the development of mountainous areas, however, the above are enough to understand the complexity and scale of the problems faced by the newly formed territorial community in the process of decentralization and administrative-territorial reform. It should be noted that one of the main reasons for this situation is the lack of proper conceptual and institutional support for public policy on integrated rural development [4].

It is obvious that a necessary condition for diversification and modernization of the economy of mountain territorial communities is to develop a holistic model of their development. The appeal to the experience of industrialized countries convincingly proves the need for the formation of a "new rural economy", which is based on the diversification of economic activity in rural areas and the "new paradigm" of rural development in a broad sense [10]. The essential characteristic of such a model is that it is "based on human priority, strategic focus on the development of local self-government and an innovative approach to business development" [11]. From these theoretical and methodological principles it is quite clear that the imperatives of sustainable development of mountain territorial communities in the region in the context of decentralization bring to the fore the problem of choosing a management model adapted to market conditions. Its formation should be based on the analysis of community opportunities, which in turn allows to clearly define the goal and determine the strategic principles of its achievement. As a result, the achievement of this goal should provide a social and economic effect: social - from the standpoint of increasing the welfare of people, and economic - in terms of increasing the competitiveness of production. The choice of strategy for the development of mountain communities cannot be arbitrary. It should be based on an in-depth analysis of the factors that limit their development potential and a realistic assessment of the creative factors, the implementation of which ensures their sustainable development and determines economic priorities. Objective analysis of creative factors should be considered in conjunction with ethnic characteristics, historical traditions of management, the propensity of the population to entrepreneurship, innovation and more. Existing factors, landscape and climatic zones, forests, mineral water, significant reserves of groundwater and surface water, minerals of industrial origin in combination with the mental characteristics of rural society project the profile of economic development of mountain communities in the plane of ecological and 
economic development, in which the organization of economic life, the development of various types of business activities, attracting investment in technical re-equipment of production, reconstruction of existing enterprises, the development of innovative areas of economic activity is carried out according to environmental criteria. This indicator regulates economic activity, business conditions, environmental standards of production of goods and services, stimulation of environmental activities in mountainous areas. The shift of the vector of economic activity in the plane of greening is due to the fact that an objective analysis of market transformations, dynamics and intensity of structural processes proves that economic dominance for mountain areas is not leading, but rather derivative, as evidenced by intensive development of tourism and recreation, recreation facilities, expansion of services, trade entrepreneurship, etc., the share of which in local budgets is constantly growing. Confirmation of this is the activity of the famous ski resorts Bukovel, Dragobrat, Krasiya, which in addition to recreation and health function have an important impact on minimizing the seasonal employment of the surrounding villages. The development of environmentally safe areas of management in Transcarpathia in the future will continue to grow, as in all newly created areas of the region in the plans of long-term development, they are considered as economic priorities.

The philosophy of management in traditional and most promising for mountain communities economic activities - forestry and agriculture - in the context of ecological and economic model is aimed at stimulating environmentally friendly industrial activities, introduction of innovative resource-saving waste-free technologies, efficient use of byproducts. At the same time, an extremely important task is the maximum possible production of final products that meet environmental standards while ensuring minimum costs in terms of integrated use of all types of resources with the lowest level of environmental pollution. Close-to-nature forestry is a better, albeit more expensive, alternative to the current age-based management system [12].

This model of management has a number of important advantages, as it allows to solve social, economic and environmental problems in a complex, which provides sustainable multifunctional management of forestry and forest use. Close to nature forestry is flexible to carry out forestry activities, as it allows to more fully realize the ecological potential of the community by increasing forest use and shift the priority of forest resources as the main economic resource in the plane of social and ecological forest use. Despite the centuries-old history, as well as the positive experience of many European countries, forestry close to nature in Ukraine and its regions has not developed primarily mutually agreed clear principles and indicators of forest management. The following principles are crucial for forestry close to nature: the continuous existence of forest cover, conservation of biodiversity, reproduction of the structure of natural forests of different ages, constant maintenance of stands, felling of wood in the amount of different principles, constant stability of water protection, protective, climate-regulating, sanitary-hygienic, healthimproving and other useful properties of forests [13]. Its undeniable advantage is that it contributes to the ecological rehabilitation of mountain communities and opens space for the effective functioning of various types of tourism and recreation, which today become one of the important economic priorities and a source of local budgets.

Implementation of the model of forestry close to nature, increase of its competitiveness provides first of all complex use of forest resources. It is not only about reforestation, logging, woodworking, but also the involvement in the economic turnover of by-products of forest use (BPFU), which are mainly concentrated in mountainous areas. According to expert estimates, the operational resources of berries, blackberries, blueberries and raspberries is about 6,135 tons, the potential resource of mushrooms, based on the minimum average of $65 \mathrm{~kg}$ per hectare of forest and other forested areas is 25-27 thousand tons, taking into account vermination and forest eating fauna. The potential of medicinal 
raw materials, according to various estimates, ranges from 418,147 tons, honey 35,930 tons. These data, which characterize the potential of secondary forest use, indicate their industrial nature and can be regarded as an important resource to stimulate the production of environmentally friendly products, intensify entrepreneurial activity, solve the problem of rural employment, increase incomes and increase financial receipts to the budgets of communities.

Given the fact that local administrations approve limits on the use of forest resources in the implementation of secondary forest uses, harvesting of secondary forest materials, issue permits for the collection and harvesting of wild-growing, they have a number of important tools to influence their rational use. This requires, first of all, the use of economic levers to increase the efficiency of the use of by-products of forest use, the most important of which are:

- substantiation of limits and standards of rent payments for business structures that carry out procurement and use for the use of BPFUs;

- attracting investment in the production of BPFU products on favorable terms for business structures that provide deep processing directly on the territory of the community;

- providing soft loans to entrepreneurs for the organization of procurement and processing of BPFU products with a complete production cycle and added value;

- stimulating the integrated and efficient use of forest resources (exemption from taxation of part of business structures profits and incomes of citizens from the procurement and sale of BPFU products).

Thus, the involvement of the outlined node of economic levers in the process of BPFU regulation significantly increases the role and competence of new territorial communities and their responsibility for the state of use of BPFU potential, which turns it into a real subject of local governance.

Processes of privatization of property are accompanied by institutionalization of new organizational and legal forms of management in agriculture of the region. Under their influence, a specific structure of business entities was formed in the region, represented by agricultural enterprises, farms and personal farms. In this triad, priority is given to households (PPF), which currently produce 91.3 percent of agricultural products, and account for $25 \%$ of the total number of employees in the region's agriculture [14].

In the structure of households there is a significant share of peasant farms, which have a commodity nature, which sell more than $50 \%$ of their products and are almost the only points of economic growth for the vast majority of mountain settlements in the region. These small areal, point manifestations of economic and social activity today are becoming a stable trend and ensure the livelihood of a large part of rural areas. Forming the structural core of business entities, they have significant potential to increase the production of organic agricultural products. Prerequisites for environmentally friendly agricultural production are the historical experience of the population in agriculture and animal husbandry, the availability of ecologically clean unpolluted land suitable for growing organic products, growing demand for organic food not only in Ukraine but also in Europe, as this niche is not filled today. There are a number of other factors, but these are enough to understand that all businesses in the countryside will sooner or later be forced to switch to ecological production systems. Moreover, the region has already accumulated experience in the use of innovative methods of farming, in particular, ecological sheep breeding, the use of biodynamic methods of growing vegetables, the production of products without the use of synthetic fertilizers. With the adoption of the Law of Ukraine "On the basic principles and requirements for organic production, circulation and labeling of organic products" (No. 2740-VIII dated 06.06.2019), significant opportunities open up to increase the production of ecological products. 
The adoption by the Verkhovna Rada of Ukraine of the Law "On State Support of Agriculture of Ukraine" (dated February 11, 2021 № 3295) has a significant impetus to stimulate the production of organic products. This law provides for the launch of three areas of state support for organic producers - the allocation of budget subsidies per unit of arable land, or one head of cattle, reimbursement of the cost of certification of organic production and reimbursement of up to $30 \%$ of the cost of seeds, feed, fertilizers. The progressiveness of the adopted law is that it laid the foundation for the transition from regional support in the form of partial compensation for the cost of product certification provided by regional state administrations to state support for organic production. Of course, state support for producers of organic products should be differentiated taking into account the natural and climatic conditions, the size of transaction costs for farmers operating in mountainous areas. It should be based on an estimate of the cost per hectare and a study of existing world experience. Calculations show that for mining operators of organic production, it should be in the range of 300-400 dollars US per 1 ha, and for alpine areas its size should be much larger.

The creation of a regulatory framework in conjunction with state-provided incentives lays the foundations for the formation of effective mechanisms in the country to regulate and support the production of organic products. The formation of such a mechanism is an extremely important task, because the rehabilitation of mountain areas can not be realized without the greening of the agricultural segment of their economy.

The complexity and scale of tasks related to the formation of ecological and economic model of economic development of mountainous areas of Transcarpathia, necessitates an objective need for clear formulation of targets, priorities and stages of implementation of the outlined range of problems to be solved in a particular time. This need is determined by the fact that the proposed model and philosophy of management of mountain communities should be based on the synthesis of economic, organizational, technological, institutional and infrastructural regulation of nature management policy of business entities (Fig. 1).

Of course, the formation of ecological and economic model of management in mountain settlements involves the choice of time priorities. In our opinion, the formation of the proposed model should include three time lags, which are interconnected and determine the time characteristics of its formation. At the first stage, it is necessary to solve economic problems caused by mismanagement and violations of environmental standards in the past and to regulate at the legislative level the organization of economic activity in mountainous areas, each of which will solve certain problems. This stage ends with the formation of the concept of sustainable development of mountain ecological and economic systems in the conditions of transformation their economy taking into account the peculiarities of nature management, development of norms and standards of maximum allowable load on ecosystem, ecological factor and assessment of their development potential.

At the second stage, measures are taken to form the procedure for attracting Ukrainian and foreign investment in the development of environmental management, the use of financial and credit instruments to stimulate the production of environmentally friendly products. The main task of this stage is the formation of the economic mechanism of nature management and regulation of business structures in the field of environmental entrepreneurship.

The task of the third stage is to include mountain producers in the sphere of crossborder economic relations, which will provide them with access to European markets and open access to investment, innovation, introduction of knowledge-intensive resource-saving technologies, which will diversify and modernize the economy of mountain communities.

The outlined stages and the formed tasks which are solved on each of them, to a large extent depend on efficiency of councils and communities functioning. 


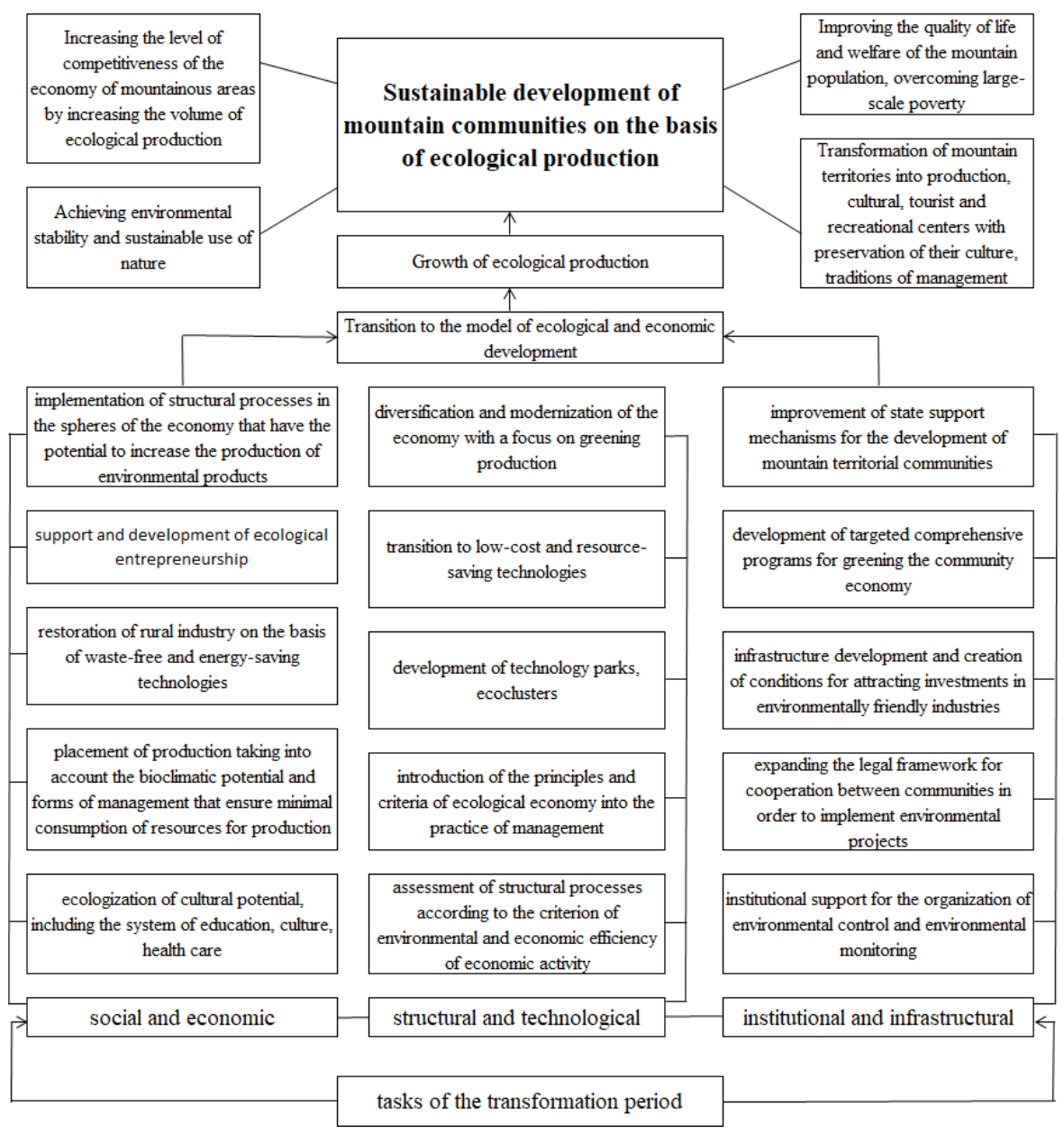

Fig. 1. Conceptual principles of formation of ecological and economic model of mountain territorial communities development.

Reforms should be carried out at the microeconomic level by creating conditions for diversification of the economy and labor activity based on private property, which should be based on the initiative of citizens [15]. This lays a solid foundation for the economic model and its basic components of labor relations, professionalism, morality, ethics, trust. These components determine the essence, nature and ideology of economic policy [15]. From the above it is clear that the imperatives of ecological and economic development of mountain communities can not be implemented spontaneously and require serious efforts to implement them through the distribution of social responsibility for the state of affairs between local authorities, business and the population. An example of such a model today is the smart community. It is based on the popular foreign concept of interaction of all stakeholders in local communities in order to intensify positive changes through the widespread use of information and communication technologies and the introduction of innovations [16].

Adapting this provision to mountainous territorial communities, the projection of which lies in the plane of greening, the "smart" community must have the following characteristics. First of all, we are talking about an innovative economy focused on 
structural transformation as a key factor in economic growth of the community. The sectoral structure of the economy, focused on the innovative path of development, should aim to overcome disintegration processes and open space for the development of innovative organizational and legal forms of management. For the mountain communities of Transcarpathia it is extremely important to form ecoclusters, which will promote cooperation, partnerships, agro-technoparks, various integration entities that geographically border and interact with business structures related to them through cooperation and specialization of organic production. This will link agricultural production, processing, sales and achieve the highest possible level of completed production and value added as the main source of community capacity. The second important characteristic of the smart community is the formation of environmental awareness of the population. In fact, we are talking about the development of the key link of territorial capital - human capital - the level of development of which determines the qualitative changes in people's lives, their environmental well-being, comfortable living conditions, professional self-realization, life prospects, and the like.

In this context, an important problem that requires a priority solution is the alienation of the population from the authorities, increasing the trust and participation of each resident of the community in the development, testing and commercialization of production and infrastructure projects in the field of greening the economic life of society.

The third important characteristic of a smart community, focused on the ecological and economic model of development, is a clear formation of environmental management policy, which means the implementation of permanent monitoring of the state of the local ecosystem, the formation of a favorable investment climate, the development of economic incentives for environmental management and control over the implementation of environmental protection activities in the community. This policy is implemented by local government bodies through a system of priorities in managing the economic complex and supporting innovatively active business entities focused on the introduction of energysaving waste-free technologies, the production of competitive products, and the development of innovative infrastructure in accordance with priority areas of management.

\section{Conclusions}

The study has shown that the processes of decentralization that are taking place in Ukraine predetermine the objective need to rethink the role and functions of mountain settlements and the introduction of fundamentally new organizational and economic mechanisms of their functioning. This process should be aimed at the multifunctionality of their development, achieved through the transition from monofunctional to a multi-structure economy, the introduction of a plurality of forms and types of economic activity, a flexible combination of collective and individual forms of entrepreneurship, agro-industrial integration, stimulation of the activities of various cooperative formations, the development of social infrastructure capable of providing meeting the maximum needs of the population in various services at the place of residence. The heterogeneity of the economic space, the existing differentiation in the level of development require a differentiated approach on the part of the state to the support and development of united territorial communities, the formation of special regimes of economic activity, especially in mountainous areas.

An important factor in the development of rural settlements is the integration of their potential with the potential of the urban economy as a whole. It will ensure the balanced development of society through the effective use of natural resource, entrepreneurial, human, social and economic potential. It is also important to ensure a balance in the interaction of innovative and traditional vectors of community development using a differentiated approach to each mountain settlement. 
Thus, the development of mountain territorial communities as areas of ecological and economic development on an innovative basis allows to preserve their identity, effectively use natural production and human potential, find their niche in the inter-territorial division of labor and overcome the systemic crisis that permeated all spheres of economic life.

\section{References}

1. Kravtsiv, V., Kolodiichuk, V., \& Kolodiichuk, I. (2018). The greening of transport and logistics systems of regional agricultural markets. Economic Annals-XXI, 171(5-6), 38-43.

2. Pitiulych, M., Hoblyk, V., Sherban, T., Tovkanets, G., Kravchenko, T., \& Sandeep G. Kumar. (2020). A sociological monitoring of youth migration movement. Journal of Critical Reviews, 7(11), 700-704.

3. Miklovda, V.P., Slava, S.S., \& Sember, S.V. (Ed.). (2018). Perspectives of economic development of territorial communities of Transcarpathia in the conditions of decentralization of power. Uzhhorod: Publishing House PE "Invazor".

4. Pavlov, O.I. (2011). Consolidated state policy of integrated development of rural areas of Ukraine: conceptual approach, model and levels. Social and economic problems of the modern period of Ukraine, 6(92), 9.

5. Kravtsiv, V., Zhuk, P., \& Bashynska, Y. (2017). Development capacity and perspectives of the renewable energy in the Carpathian region of Ukraine. Economic Annals-XXI, 168(11-12), 73-77.

6. Samolotov, P. (2004). Development strategy of the Ukrainian Carpathians: formation and implementation mechanisms. Regional economy, 1, 116-124.

7. Schirpke, U, Scolozzi, R., Dean, G., Haller, A. Jäger, H., Kister, J., Kovács, B., Sarmiento, F.O. Sattler, B., \& Schleyer, C. (2020). Cultural ecosystem services in mountain regions: Conceptualising conflicts among users and limitations of use. Ecosystem Services, 46, 101210.

8. Klima, K., Kliszcz, A., Puła, J., \& Lepiarczyk, A. (2020). Yield and profitability of crop production in mountain less favoured areas. Agronomy, 10(5), 10050700.

9. Main Department of Statistics in Transcarpathian region. (2020). Demographic situation in the region in 2019. Statistical bulletin. Uzhgorod.

10. Drabenstott, M., \& Henderson, J. (2006). A New Rural. Economy: A new role for public policy. Management. Quarterly, 47 (4), 8.

11. Hubeni, Yu. (2007). Rural development: some aspects of European theory and practice. Economy of Ukraine, 4, 67.

12. Shershun, M.Kh. (2010). Forest as a factor in preserving the ecosystems of mountainous regions of Europe. In Sustainable development of the Carpathians and other mountain regions of Europe, 133. Uzhgorod: Timpani.

13. Cherniavsky, M.V. (2010). Close to nature forestry as a strategy of forestry in the Carpathians. In Sustainable development of the Carpathians and other mountainous regions of Europe, 140, Uzhgorod: Timpani.

14. Transcarpathia 2019. (2020). Statistical Yearbook. Uzhgorod.

15. Heets, V.M. (2009). Society, state, economy: phenomenology of interaction and development. Kyiv: Institute of Economics and Forecasting of the National Academy of Sciences of Ukraine.

16. NAS of Ukraine. (2019). Economic efficiency vs social justice: priorities of Ukraine's development at the stage of overcoming the crisis. Kyiv. 